\title{
The Variants of the se vivo fecit Expression in Latin Language Inscriptions
}

\author{
Nóra Zelenai \\ (Eötvös Loránd University, Budapest)
}

\begin{abstract}
The se vivo fecit formula (or any variants of it) occurs almost 1400 times in the Latin epigraphic corpus. This fact attracts our attention, because, according to the rules of the classical grammar, the expression should be seen as incorrect, since the semantic subject of the ablative absolute construction corresponds to the subject of the main clause. This incorrect formula was nevertheless part of the Latin funerary epigraphic language for more than five hundred years. We can find it in inscriptions from the Iberian Peninsula to the Balkans, from Africa up to Gallia, and the form was considerably widespread in the area of Rome, in the west side of NorthAfrica, and in the Balkan provinces. It is remarkable that (especially in Rome) the phonetic and morpho-syntactic changes of the Latin language have induced further interior mutations of the formula. We have many examples in which the adjective of the expression (vivus) stands in the nominative or in the accusative instead of the morphologically correct ablative. Therefore, we can find variants as se vivus, se vivum, etc. The aim of this paper is to explore the spread of each variant of the se vivo fecit formula, and to give a possible explanation for the occurrence of trends that do not meet our expectations.
\end{abstract}

\section{Keywords}

funerary inscriptions; dialectology; the language of Rome; ablative absolute; formular language; se vivo fecit

\footnotetext{
The present paper was prepared within the framework of the project NKFIH (National Research, Development and Innovation Office, former OTKA Hungarian Scientific Research Fund) No. K 108399 and K 124170 entitled "Computerized Historical Linguistic Database of Latin Inscriptions of the Imperial Age" (see: http:// Ildb.elte.hu) and of the project entitled "Lendület ('Momentum') Research Group for Computational Latin Dialectology" (Research Institute for Linguistics of the Hungarian Academy of Sciences).
} 


\section{An ablative absolute corresponding to the subject of the main clause}

This paper is on the grammatically incorrect expression se vivo fecit, which appears almost 1400 times in Latin inscriptions from the first up to the seventh century AD, from a large part of the Roman Empire. It was used in funerary inscriptions when the customer wanted to express clearly that the tomb had been ordered by him during his lifetime and not just after his death, by his will. In these cases, the customer either ordered the tomb for his whole family (as it is typical in the earlier period), or only for himself (which custom has become usual in the Christian era).

This expression is worth the investigation due to the fact that we can see here an ablative absolute construction which includes a temporal phrase: Marcus se vivo fecit has the same meaning as Marcus, dum vivus erat, fecit ('Marcus has made it while he was alive'). However, in our expression the ablative absolute should not be used, according to the main rules of classical Latin grammar, because the subject of the construction ( $s e$ ) and that of the main clause (Marcus) refer to the same person. In such cases, in classical Latin a participle or an adjective is used as an apposition, which agrees in gender, case and number with the word it refers to. ${ }^{1}$ Therefore, in our expression a nominative vivus or a dative vivo (if sibi is also present in the sentence) should stand in the place of se vivo. As it does several times: the correct version's (vivus fecit or sibi vivo fecit) occurrences are multiple of the form using the ablative absolute. But the high number of the incorrect version should not let us ignore that, when we find se vivo in an inscription, it is not a result of an individual mistake. We are dealing with a formula, which became conventional despite containing an incorrectly used ablative absolute construction.

However, using the ablative absolute when its semantic subject corresponds to that of the main clause is not absolutely unfamiliar to the Latin language, we can find some examples of it also in classical authors, like Cicero or Caesar. It is a phenomenon that the Latin grammatic literature tries to explain. Following the new edition of the Lehrbuch der lateinischen Syntax und Semantik of Hermann Menge, there are special conditions which allow the use of this construction. These conditions can be separated in two groups: using the ablative absolute, although its subject refers to the same person as that of the main clause, is allowed either when the emphasis falls on the sameness of the subject of the ablative absolute and the main clause, or when it is necessary for the clear meaning of the sentence. ${ }^{2}$ It is generally not easy to decide objectively if there is any intention of emphasis in a sentence, but maybe we can say that concerning our expression, there is no semantic reason to emphasize particularly that the subject and the attribute refer to the same person. The other condition is not fulfilled either as well in our case. In these inscriptions the subject is always expressed in the main clause, and usually the apposition stands close to it. Therefore, it is not necessary to use the ablative absolute to make the sentence's meaning clearer.

1 Hofmann \& Szantyr (1972: pp. 139-140); Menge (2009: p. 723); Väänänen (1981: p. 167).

2 Menge (2009: p. 723). 
Another work, the Introduction au Latin Vulgaire of Veikko Väänänen, approaches the problem in another way. It says that the use of the ablative absolute when its semantic subject corresponds to that of the main clause was usual in early Latin, and it survived in formulas through later periods. ${ }^{3}$ In our case this explanation cannot be satisfactory because, although the phenomenon really appears more often in earlier Latin literature (as for example in Plautus or Terence), the se vivo formula does not seem to have such an early origin. We do not have any inscriptions using the expression from the republican period, its first appearance is from the second half of the first century BC.

Väänänen claims that the ablative absolute construction was not the part of the spoken Latin in the later periods of the language, it lived on only in the (usually ceremonious) formulas (as me, te, illo, etc. lubente, invito, praesente, absente). The semantic subject of these formulas often corresponds to the subject (or the object) of the main clause, which use was usually rejected by the classical authors. ${ }^{4}$ This supposition seems to be probable, since we know that complicated constructions were not popular in the spoken language, and the ablative absolute does not exist in the roman languages. Nevertheless, we did not find any example of the incorrect use of the mentioned formulas in the inscriptions: the subject of the ablative absolute and that of the main clause never refers to the same person. In the case of correspondence of the subjects, the epigraphic language uses the participle, also in the solemn formulas. ${ }^{5}$ Thus, we cannot accept the theory that the se vivo fecit expression is one of the epigraphic formulas using the ablative absolute construction incorrectly.

The origin of the se vivo fecit formula is uncertain, but we have data on when and where it was used. Evidently, we cannot draw any conclusions based on the absolute number of the inscriptions in which we can find the formula. Since the amount of the epigraphic material, the proportion of the funerary inscriptions in the whole epigraphic corpus we are working with, and the changes in the funerary habits (that is how usual was to order one's own grave before one's death) are all factors that influence the number of examples of se vivo. The most appropriate method is to compare the number of inscriptions using the ablative absolute (se vivo fecit) and that of using the apposition (vivus fecit or vivo sibi fecit).

The first map informs us about the funerary habits in the Roman Empire (without any chronological differentiation). ${ }^{6}$ It shows that making one's own tomb before one's death was fairly general in the society of the Northern regions. We can see the highest proportion of the form in Noricum, where the $43 \%$ of the funerary inscriptions (written in Latin) contain the vivus adjective (in any form). The provinces around attest a lower and gradually reducing, but still high proportion. ${ }^{7}$ The sharpest dividing line was drawn

3 Väänänen (1981: pp. 166-167).

4 Ibid.

$5 \quad$ E.g. the popular votum solvit libens merito formula.

6 We know approximately 6600 examples of the vivus fecit and 1400 occurrences of the se vivo fecit from the whole territory of the Roman Empire (based on the data of the EDCS).

7 The proportion of the funerary inscriptions containing the vivus adjective (in any form) compared to all 
in the West: south of the Pyrenees we can find the word vivus only in a remarkably low amount. ${ }^{8}$ The decrease is less radical in Italy, ${ }^{9}$ and specifically in the east side of the empire. ${ }^{10}$ However, we must take in consideration that the scarcity of the Latin inscriptions in the Peloponnesos and in the Asian part of the Empire render dubious the possibility of any valid statistical analysis.

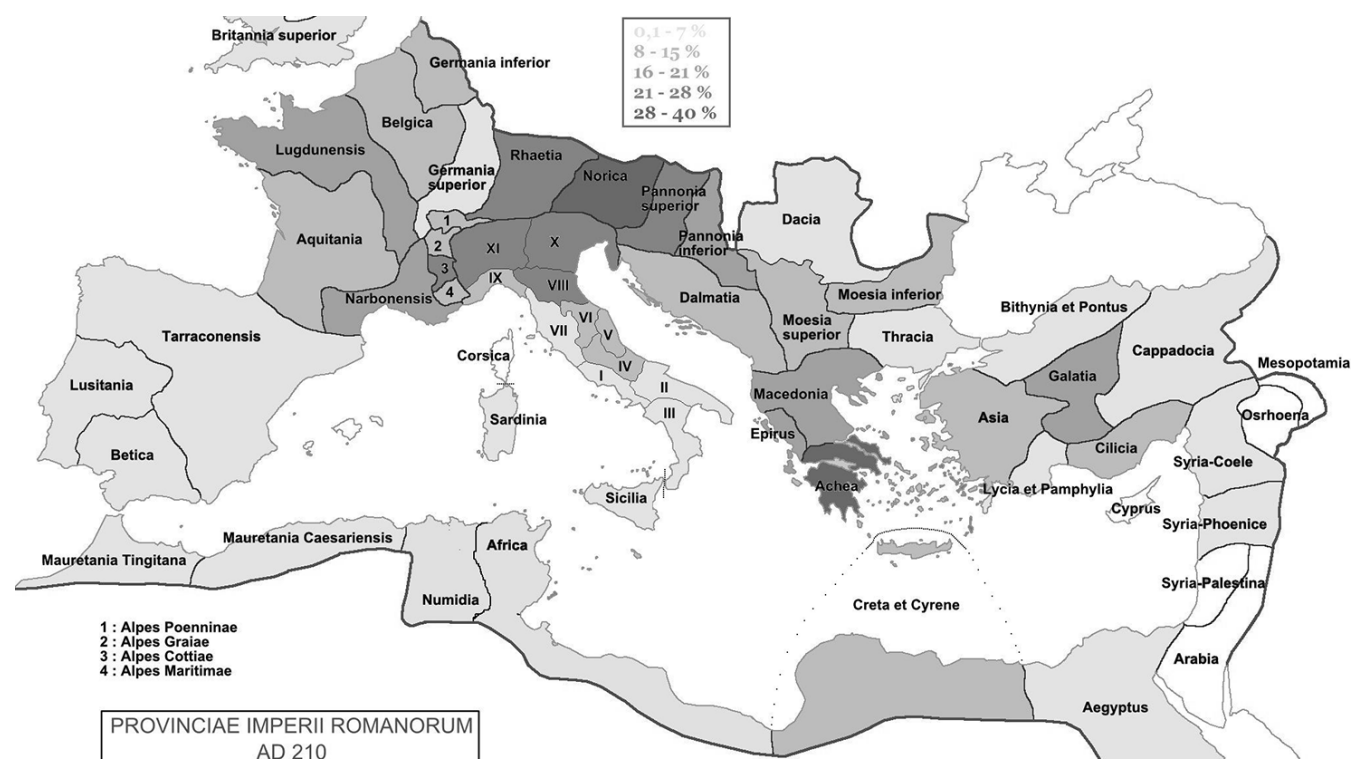

1. map: Proportion of the funerary inscriptions using the vivus adjective [(vivus fecit + se vivo fecit) / all funerary inscriptions*100]

The se vivo fecit expression can be found in the west side of Northern Africa, in the Iberian Peninsula, in Gallia, in Italia, in the Balkans and in a very low number in Pannonia Superior, in Dacia and in Bithynia et Pontus. ${ }^{11}$ The formula was known only in the west-

funerary inscriptions from the province: Raetia $21 \%$, Alpes Cottiae $24 \%$, Transpadana $23 \%$, Aemilia $22 \%$, Venetia et Histria 28\%, Pannonia Superior 26\%.

8 The proportion of the funerary inscriptions containing the vivus adjective (in any form) compared to all funerary inscriptions from the province: Alpes Poeninae 13,5\%, Alpes Graiae 10\%, Alpes Maritimae $11,2 \%$, Germania Inferior 8\%, Belgica 12\%, Lugdunensis 14,9\%, Aquitania 12,2\%, Gallia Narbonensis $18,9 \%$, Lusitania $0,5 \%$, Baetica $0,6 \%$, Mauretania Tingitana $0,5 \%$, Mauretania Caesariensis $0,7 \%$, Africa Proconsularis $0,6 \%$, Numidia $1,5 \%$.

9 The proportion of the funerary inscriptions containing the vivus adjective (in any form) compared to all funerary inscriptions from the province: Umbria 7,3\%, Picenum 9,8\%, Samnium 10,7\%, Etruria 5\%, Latium et Campania (without Rome) 3,4\%, Roma 2,4\%, Apulia et Calabria 5\%, Bruttium et Lucania 2,6\%, Sicilia $3,1 \%$.

10 The proportion of the funerary inscriptions containing the vivus adjective (in any form) compared to all funerary inscriptions from the province: Pannonia Inferior 15,6\%, Dalmatia 7,8\%, Moesia Inferior 10,5\%, Moesia Superior 13,2\%, Macedonia 15,4\%, Achaia 39,1\% (but we must take into account that we know only 69 Latin funerary inscriptions from here), Thracia 1,4\%, Bithynia et Pontus 3,9\%, Cappadocia 5,8\%, Lycia et Pamphylia 6,1\%, Cilicia 10,5\%, Creta et Cyrenaica 10,5\%, Asia 11,9\%, Galatia 15,63\%.

11 We know only 1 example from Bithynia et Pontus. 
ern basin of the Mediterranean Sea, it was absolutely absent in the Asian provinces and in the eastern part of Northern Africa, as also in Western Europe beyond the Mediterranean areas. Looking at the whole empire, the examples with the ablative absolute (se vivo) make up one fifth of the expressions using the vivus adjective.

The second map, which illustrates the proportion of the se vivo form (compared to the number of inscriptions using the vivus adjective) in each province, shows that the main centre of the se vivo fecit formula was Numidia, where vivus was used as part of an ablative absolute construction in the $81,9 \%$ of its occurrences. In the adjoining provinces (Mauretania Caesariensis and Africa Proconsularis), the se vivo fecit and the vivus fecit types were used with nearly the same frequency. ${ }^{12}$ The proportion of the se vivo form in the Iberian Peninsula is significantly higher than that on the other side of the Pyrenees (Aquitania and Gallia Narbonensis). ${ }^{13}$ Considering this fact, it is surprising that we have not found any example of the se vivo form in Mauretania Tingitana (which borders Mauretania Caesariensis). Thus we cannot affirm that its relatively high proportion in the Iberian peninsula, specifically in Lusitania and Baetica, ${ }^{14}$ is the result of the popularity of the formula in Africa.

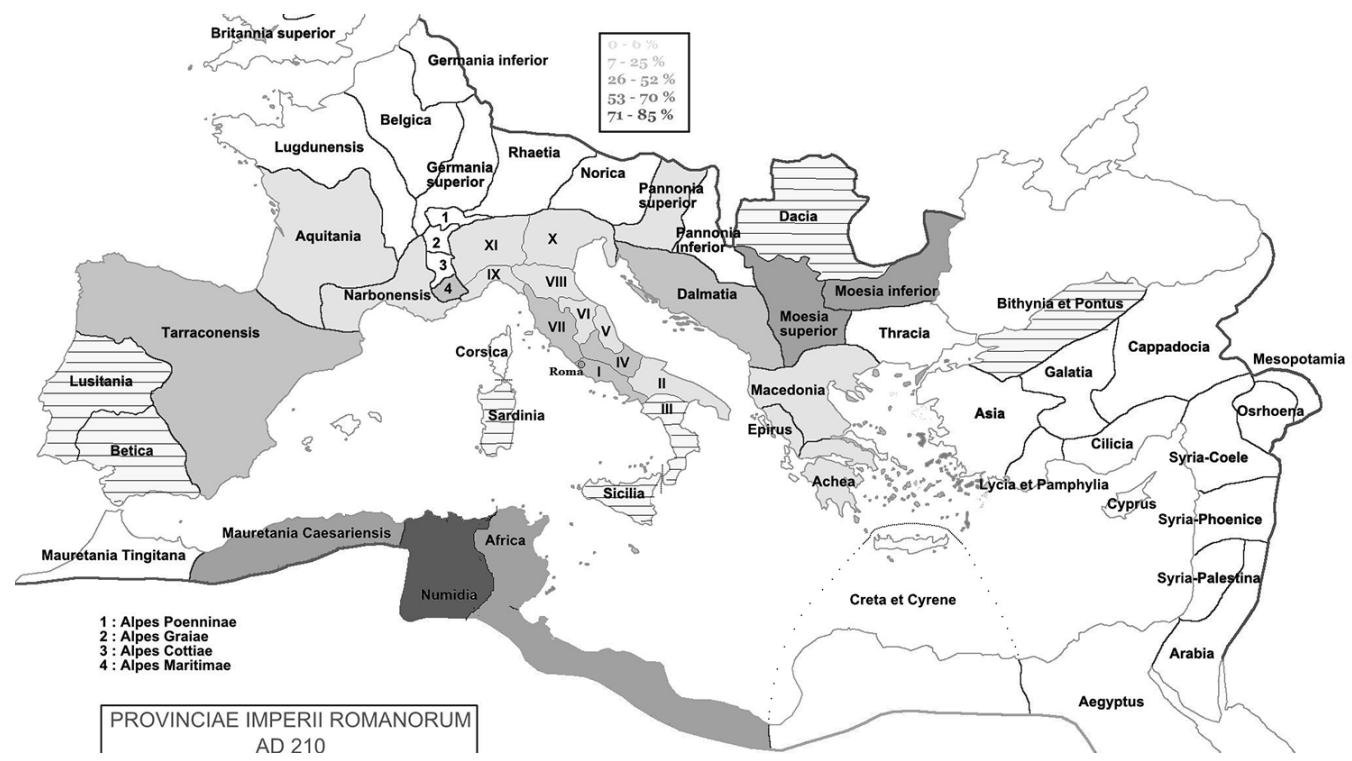

2. map: Proportion of the se vivo fecit formula in the inscriptions using the vivus adjective [se vivo fecit / (vivus fecit + se vivo fecit)*100]

12 The occurrences of se vivo compared to all occurrences of the vivus adjective (in any form): Africa Proc: 62,4\%, Mauretania Caes: $45 \%$.

13 The occurrences of se vivo compared to all occurrences of the vivus adjective (in any form): Aquitania $1,1 \%$, Gallia Narbonensis $1,64 \%$.

14 The occurrences of se vivo compared to all occurrences of the vivus adjective (in any form): Hispania Citerior 14,3\%, Baetica 33\%, Lusitania 69,2\% (but it means only 15 examples from Baetica and 13 from Lusitania). 
Another region where the density of the se vivo form was above average was the northeastern part of the Balkans. In Moesia Inferior and Superior we can find it in more than one third of the inscriptions that were ordered during the life of the addressees. ${ }^{15}$ However, its proportion was much lower in the adjoining provinces: except of Dalmatia, where it reaches $7,5 \%$, we know of only an insignificant number of occurrences. ${ }^{16}$

Beyond the two regions mentioned above, the se vivo formula was often used also in the capital of the empire, where the vivus adjective stands in an ablative absolute construction in the $51,5 \%$ of the occurrences. The influence of Rome can be demonstrated in Latium et Campania, where the proportion is $25 \%$, while the other neighbouring provinces (Samnium and Etruria) did not follow the tendency. ${ }^{17}$ However, they still have a higher proportion compared to the other parts of Italia, where the se vivo form occurs quite rarely. ${ }^{18}$ Although it seems to be popular in Bruttium et Lucania and Sicilia (which phenomenon could indicate a connection between Africa and Rome), ${ }^{19}$ the extremely low number of the examples of both type (vivus and se vivo) requires cautiousness.

Since the se vivo formula was regularly in use in Northwestern Africa, in the Balkans and in the larger territory of Rome, we are going to focus only on these regions.

From the Balkans, thanks to the Epigraphic Database Heidelberg $($ EDH $),{ }^{20}$ almost all inscriptions are dated at least within a two-hundred year period. If we employ the dating method of the Computerized Historical Linguistic Database of Latin Inscriptions of the Imperial Age $(L L D B),{ }^{21}$ which takes the mean of the termini post quem and ante quem, ${ }^{22}$ with a modest correction, ${ }^{23}$ we get the following results: from the Balkans we know 8 examples from the first, 50 from the second, 33,5 from the third, and 4,5 from the fourth centuries AD.

These absolute numbers cannot account for the change of the popularity of the formula, since the amount of the inscriptions in which the expression potentially occurs is not equal in each period. So, the quantity of the inscriptions using se vivo should be

15 The occurrences of se vivo compared to all occurrences of the vivus adjective (in any form): Moesia Inferior $37,7 \%$, Moesia Superior $36,1 \%$.

16 The proportion of the ablative absolute is $20 \%$ in Dacia, but we know only 10 examples containing the vivus adjective.

17 The occurrences of se vivo compared to all occurrences of the vivus adjective (in any form): Etruria 9,1\%, Samnium 7,4\%.

18 The occurrences of se vivo compared to all occurrences of the vivus adjective (in any form): Liguria 3\%, Transpadana 3,2\%, Venetia et Histria 1,1\%, Aemilia 2,2\%, Umbria 3,8\%, Picenum 2,6\%, Apulia et Calabria $6,6 \%$.

19 The occurrences of se vivo compared to all occurrences of the vivus adjective (in any form): Bruttium et Lucania $35,7 \%$, Sicilia $7,7 \%$.

20 Cf. http://edh-www.adw.uni-heidelberg.de/home.

21 Adamik (2016: p. 24).

22 „In division concerning centuries, the selected data forms are automatically inserted in centuries, the data forms with a longer date than a year are inserted by averaging their dates as follows: e.g. a data form with a date 151-200 AD will be inserted in the 2nd century AD by the date $176 \mathrm{AD}$, a data form with a date 251-350 in the 4th century AD by the date $301 \mathrm{AD}$ and so forth."

23 In those cases when the arithmetic mean is the turning point of two centuries, I put half an example in both of them. 
compared to the number of the funerary inscriptions from the Balkans ${ }^{24}$ in each century respectively. Unfortunately, due to the problems of the searching system of the $E D H$, we cannot define the chronological distribution of all funerary inscriptions divided the data by centuries, we can only take into account the potentially Christian character of the examples. The inscriptions signed as Christian by the Epigraphik-Datenbank Claus / Slaby $(E D C S)^{25}$ are probably from the fourth century or later periods, while the non-Christian ones are mostly older. Obviously, this method can indicate a statistical distortion, but we can get an approximate picture of the chronological distribution of the formula.

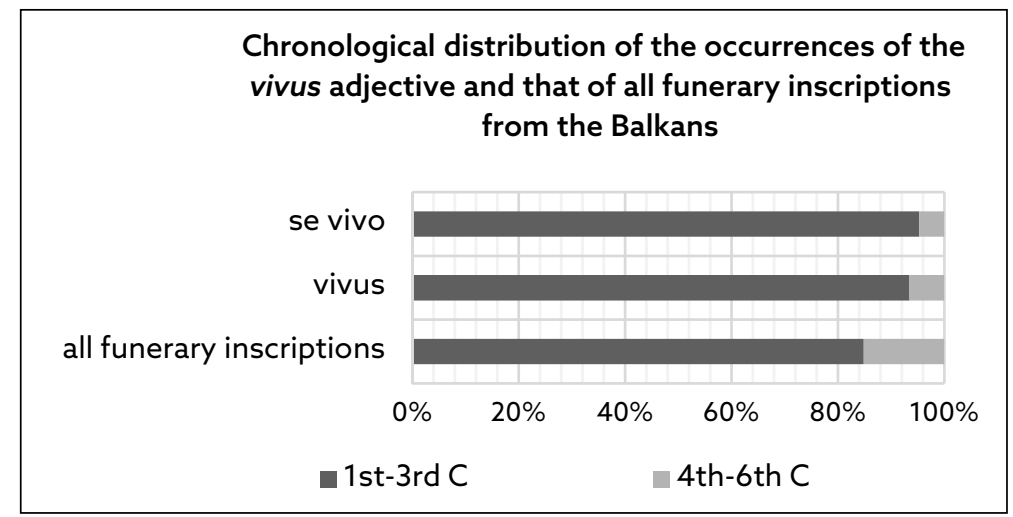

\section{1. chart}

The chart shows that in the Balkans, the culture characterized by Latin inscriptions was highly reduced by the christian period (only the $15 \%$ of the funerary inscriptions were Christian). ${ }^{26}$ Still this reduction was not as drastic as the reduction of the inscriptions using the vivus adjective as an apposition or in the ablative absolute. It means that the habit of ordering the epitaphs before one's death has lost its popularity in these provinces. However, this was a modest change, the extremely low proportion of the later period $\left(4^{\text {th }}-6^{\text {th }}\right.$ centuries $)$ concerning the examples using vivus or se vivo is due to the radical decrease of the number of all Latin funerary inscriptions from this time. Comparing the chronological distribution of the occurrences of se vivo and vivus fecit, we get similar results: the proportion of the later period reaches around $6 \%$ in both case. ${ }^{27}$ So, the $s e$ vivo fecit form remained a rarely used alternative variation of the vivus fecit expression also in the Christian times.

There is an interesting development that, unfortunately, we do not have enough space in the present paper to expand on, but that is worth to mention. Almost exclusively in the Balkans, the inversion of the expression (that is vivo se instead of se vivo) was also

24 Macedonia is excluded from the analysis, since the formula was almost unknown (we have only 1 datum from here).

25 Cf. http://db.edcs.eu/epigr/epi.php?s.

$261189 / 7846$ inscriptions are christian.

27 Vivus fecit: 37 / 565, se vivo fecit: 5 / 96 inscriptions are christian. 
used, as also the vivo suo form, that Giovanbattista Galdi thinks to be the result of the considerable Greek influence in this region. ${ }^{28}$ This expression will be the topic of a future investigation.

Now we are going to focus on the chronological distribution of the occurrences of the se vivo form in the other two regions where its use was popular. From Africa (especially from Numidia) we know 198 examples of the se vivo form, a corpus almost absolutely undated. Only 4 (2\%) of the inscriptions, which are included in the corpus of the Inscriptiones Latinae Christianae Veteres (ILCV), are surely Christian, any Christian features are absent from the others. Beyond these, we have only 1 datum for the vivus fecit expression from the Christian centuries, while $10,5 \%$ of all the funerary inscriptions came from this period. ${ }^{29}$ Based on this fact, we assume that both the se vivo fecit and the vivus fecit expressions were alive in the early imperial African Latin (that is from the first to the third centuries), and they were almost totally vanished in the fourth century.

We must mention here a variant of our expression. Africa was the homeland of the se vivente formula, which formula uses the participle of the verb vivo instead of the adjective. Nearly $80 \%$ of the occurrences of this variant are from the African provinces, however it does not mean that it is a specific feature of this region. We know 18 African examples of se vivente / se viventibus, ${ }^{30}$ which is only $8 \%$ of the occurrences of the expression. Among the other 5 examples, there are 2 from Rome, 2 from the Balkans and 1 from Liguria.

\section{The variants of the se vivo formula in inscriptions from Rome}

In what follows, we are going to focus on Rome and Latium, where 966 inscriptions using our formula are attested. Unfortunately, the 61 data from Latium have to be excluded from the chronological analysis because almost all of them are undated, thus we can investigate only the city of Rome. We have many undated inscriptions from here as well, but luckily there is a corpus (Inscriptiones Christianae Urbis Romae) which brings together all of the Christian inscriptions from the capital of the empire, thanks to that we can specify an approximate date. The inscriptions which are included in this collection are from the Christian period of the empire, that is (as we explained above) they are from between the fourth and the sixth century, the ones not included in the corpus are probably from the first three centuries. With this method we can study the chronological distribution of the se vivo fecit formula in Rome, and the result is absolutely different from the situation we have found in the Balkans or in Africa.

28 Galdi (2002: pp. 75-94).

$295795 / 55286$ inscriptions.

30 CIL 8, 5466; CIL 8, 23329; CIL 8, 28076; ILAlg 1, 1919; AE 2003, 1965; AE 2013, 1958; CIL 8, 2122; CIL 8, 3919; CIL 8, 4453; CIL 8, 4610; CIL 8, 4614; CIL 8, 8252; CIL 8, 17761; ILAlg 2.3, 8130; ILAlg 1, 2415; AE 1974, 725; CIL 8, 3911; CIL 8, 10853. 


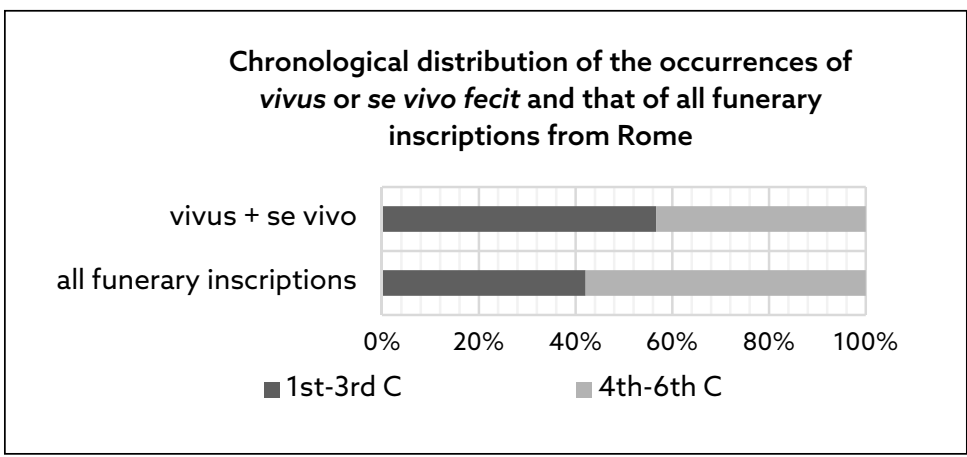

2. chart

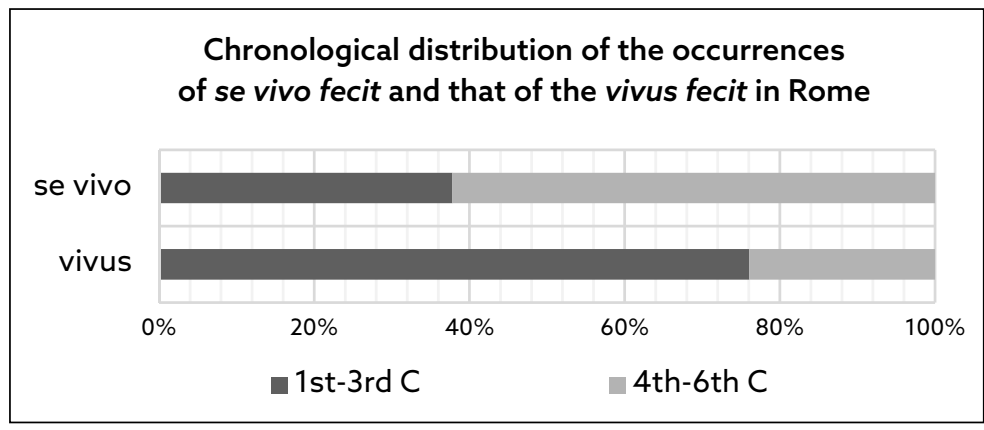

3. chart

First we are going to investigate the changes of the funeral habits. If we look at the second chart, we affirm that the proportion of the later period is $43,4 \%$ concerning the inscriptions using any form of the vivus adjective, ${ }^{31}$ while it reaches $57,9 \%{ }^{32}$ if we look at all the funerary inscriptions found in Rome. Which means that the habit of ordering one's own tomb before one's death (and note this fact in the text of the inscription) fell out of fashion after the third century (just as in the Balkans and in Africa), nevertheless it did not disappeared.

Looking at the proportion of the occurrences of the two types of the expressions with the vivus adjective we have seen above that it was approximately constant in both of the regions examined, though in the Balkans the expression using the ablative absolute has begun to disappear a little bit faster than the vivus fecit form. In Rome we found a quite different situation. On the third chart, which shows the chronological distribution of the vivus fecit and that of the se vivo fecit forms, we can see that the proportion of the occurrences from the later centuries is $63 \%$ concerning the expression with the ablative

31750 inscriptions.

3241693 inscriptions. 
absolute construction, ${ }^{33}$ while only the $25 \%$ of the examples of vivus fecit is from this period. ${ }^{34}$ Therefore we can draw the conclusion that the expression with the apposition was in vogue earlier, and the se vivo formula became more popular later, from the fourth century on.

To sum up this part of the paper: the se vivo formula was in use in a large part of the Roman Empire, but it was frequently used only in the West side of Northern Africa, in the Balkans, in Latium et Campania and in the city of Rome. In Africa and in the Balkans, it was characteristic of the pre-Christian imperial period, that is of the first three centuries $\mathrm{AD}$, in the Balkans most of all in the second and in the third centuries. In Rome it became even more popular later, while the use of vivus fecit was used rarelier in the Christian times.

In Rome, we can find interesting variants of the se vivo expression, which the epigraphic literature generally mentions, but does not pay attention to their analysis. For example, none of the literature informs us about the fact that these forms are typical features of inscriptions found in Rome or in Latium et Campania, and we can see them only accidentally elsewhere. The peculiarity of this fact is that, although the morphologically correct formula (that is an ablative absolute) can be se vivo (masculine singular), se viva (feminine singular) or se vivis (plural, in both gender), there are many inscriptions where the adjective stands in another form because of phonologic or morphologic mutations.

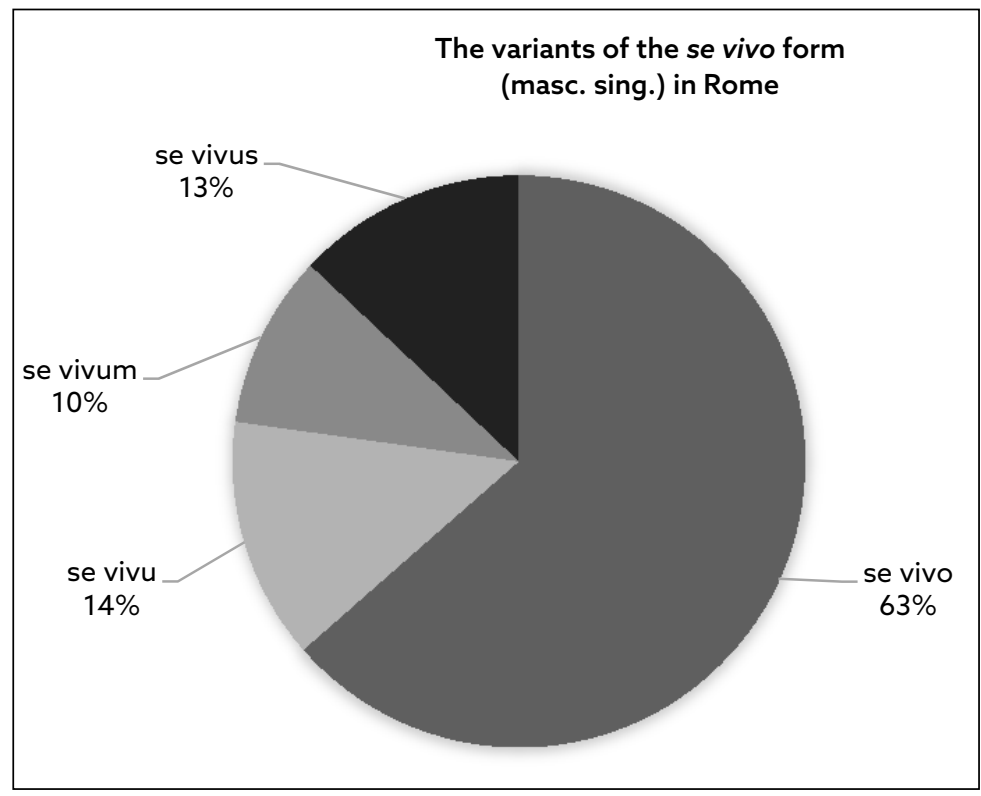

4. chart

33332 inscriptions from the $1^{\text {st }}-3^{\text {rd }} \mathrm{C}$, and 546 from the $4^{\text {th }}-6^{\text {th }} \mathrm{C}$.

34648 inscriptions from the $1^{\text {st }}-3^{\text {rd }} \mathrm{C}$, and 204 from the $4^{\text {th }}-6^{\text {th }} \mathrm{C}$. 


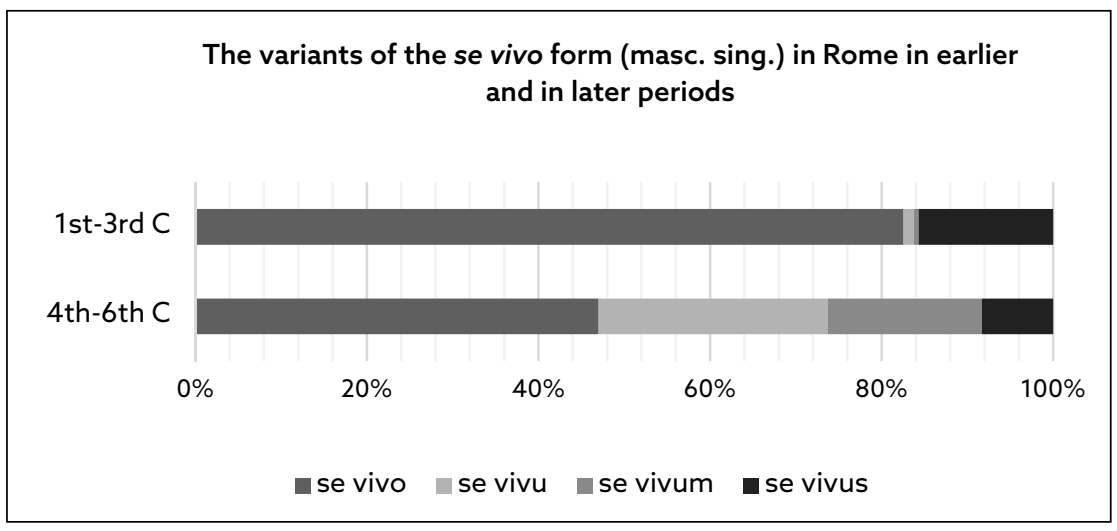

\section{5. chart}

First, we discuss the masculine singular: beyond the 279 examples of se vivo, we have 60 inscriptions with se vivu, ${ }^{35} 43$ with se vivum ${ }^{36}$ and 57 with se vivus. ${ }^{37}$ Unfortunately, it is impossible to decide, which case the se vivu forms are in. They could be in the ablative, where the final -o has become an $-u$ because of the tendency in the vulgar Latin language that the articulation of the mid vowels (classical Latin $e$ and $o$ ) became mid-close, ${ }^{38}$ so they have been similar to the close one's (classical Latin $i$ and $u$ ). But it is also possible that vivu derived from the accusative or from the nominative form (vivum or vivus) as a result of the vanishing of the final consonant $(-m$ or $-s) .{ }^{39}$ These changes were in process during the same time,${ }^{40}$ so we cannot draw any conclusions based on the chronological distribution of the se vivu forms, which shows the evident predominance of the occurrences in the later period.

The 43 inscriptions containing the se vivum form are also from the Christian era (only one of them is older), whereas the se vivus was used from the early imperial age, the oldest inscription with se vivus is from the second half of the first century AD. ${ }^{41}$ The form has not disappeared later; it is attested in inscriptions also from the fifth century.

35 E.g. ICUR II, 6458. Urbicus se ' $\mathbf{v}=\mathbf{B}^{\prime} \mathbf{i}^{\prime} \mathbf{v}=\mathbf{B}{ }^{\prime} \mathbf{o}^{\mathbf{0}}=\mathbf{V}^{\prime}$ fecit $\mid$ cum compare sua (Urbicus has made it during his lifetime with his wife).

36 E.g. ICUR VI, 17347. Victor fecit se I viv' ${ }^{\prime}=\mathbf{O M}$ ' sibi et sui $\{\text { bu }\}_{\mathbf{s}}$ (Victor has made it during his lifetime for himself and for his ones).

37 E.g. CIL VI, 13135. D(is) M(anibus) | Aurelius Isidorus / se viv' o=VS ' compara|vit sibi et Septimiae / Veneriae Theodor<a>e (Aurelius Isidorus has bought it during his lifetime for himself and for Septimia Veneria Theodora).

38 Except when they are short and stressed.

39 We do not have enough space here to expand on the complicated problem of the vanishing of the word final consonants. For recent results concerning the question of the situation of the word-final $-s$, see Adamik (2017). The comparative analysis of the weakening of the word-final $-m$ and $-s$ will be the topic of a future paper.

40 Herman (2000: pp. 32-36 and 39-41).

41 CIL VI, 20149: D(is) M(anibus) | Ti(berius) Iulius Nepos se vi $\mathbf{v}=\mathbf{B}$ ' 'o=VS ' conparav|it sibi et suis libert(is) liberta(bus) posterisq(ue) | eorum itemque et Statiliis liberti<s> | libertabus co<n $>$ iugis suae 
We do not take into consideration the corpus from Latium et Campania, because of the problems with its dating. Still, among the 60 inscriptions, there is not one with se vivu, only one with se vivum, but we have ten examples of se vivus. Based on this distribution we might risk the statement, in spite of the insufficient number of examples, that the corpus from Latium is older than the fourth century, which would mean that later, in the Christian period, our expression (in any form) was generally used only in the city of Rome.

The high number of the se vivum form in the later centuries is not surprising; the confusion of the accusative and the ablative was not rare in the late Latin language. The fact that the other part of the formula, the third person of the reflexive pronoun, has the same form in accusative and in ablative (both of them are se), could be a contributory factor in the frequent use of the accusative instead of the ablative. Because of this identical morphology, it is impossible to decide whether the se vivum was an accusative absolute or an absolute construction with an ablative (se) and an accusative part. We have epigraphic examples for both. ${ }^{42}$ There is only one inscription with the formula in which we certainly see an accusative absolute, since in the first person plural the two cases have different endings: the nos vivos instead of nobis vivis is definitely in accusative absolute. ${ }^{43}$

The problem of the se vivus form is much more complicated. The possibility of the confusion of the ablative (vivo) and the nominative (vivus) can be excluded, because the nominative was the most fixed case, and because this form was born much earlier than the erosion of the nominal case system started. The literature agrees that the se vivus form is a contamination of the ablative absolute (se vivo fecit) and the grammatically correct expression with apposition (vivus fecit). ${ }^{44}$ This explanation is acceptable, the formula probably was the result of contamination, but we should not ignore the fact that it has become fixed as a formula, since it made up about $10 \%$ of all the occurrences of the se vivo-type found in Rome, and it was in use for almost five hundred years. How was it interpreted throughout five centuries?

We can give various explanations of the se vivus form, which are difficult to distinguish. We can presume that the reflexive pronoun, which in classical Latin had only four cases, has got also a nominative in vulgar Latin, or we might understand the $s e$ in this form as an indeclinable particle, which emphasizes the connection between the adjective (vivus) and the subject of the phrase. Both of these explanations are problematic because, as it was mentioned above, the emphasis does not have any role in this expression. But to test the hypothesis, we have looked for inscriptions where instead of $s e$, another pronoun (for

(Tiberius Iulius Nepos has bought it during his lifetime for himself, for his freedmen, freedwomen and for their descendents, and also for the Statiliuses, the freedmen and freedwomen of his wife).

42 Acc. abs.: e.g. AE 1965, 76: vivent ' ibu=E's | Cardili ' o=VM' | et Avita $\{\mathrm{m}\}$ (Cardilius and Avita during their lifetime); Abl. abs. accusativis permixtus: Pl. RIU 3, 889: Domitianus () viv' u=O 's | sibi fecit / adiutantibus nepo|t ' ibu=E's su ' $\mathrm{i}=\mathrm{O}$ 's fili ' ae=ES ' fili ' $\mathrm{i}=\mathrm{O}$ 's Gregor/io et Laurentio fratr ' ibu=E 's (Domitianus () has made it for himself, with the support of his grandsons, Gregorius and Laurentius, the sons of his doughter, who were brothers).

43 ICUR 5, 13304: Bonosus pater orfanu[s et Vic]tor $<\mathrm{i}>\mathrm{a}$ uni ' $\mathrm{c}=\mathrm{K}$ 'a $\mid$ filia fecimus no ' bi=O ' $\mathbf{s}$ vi ' vi=BO 's $\mathrm{Iu}[\mathrm{lio}] \mathrm{|}$ H $>$ ermogeneti dulcissim[o uni]co filio (We - Bonosus, the orphaned father, and Victoria, his only doughter - have made it during our lifetime for Hermogenes, the only son).

Hofmann \& Szantyr (1972: p. 140); Galdi (2002: p. 467). 
example hic, ipse, etc.) stands next to the vivus adjective and has an emphatic function. ${ }^{45}$ We have found only five examples, and four of them were with female subject where the emphatic pronoun could express that the woman has made the tomb as an autonome subject, not under the care of a guardian.

So, it seems to be apparent that the phenomenon is not due to an emphasis here, Giovanbattista Galdi has observed rightly that the reflexive pronoun has lost its value in the se vivus expression. ${ }^{46}$ The most radical opinion about this form was made by Konjetzny in $1908 .{ }^{47}$ His theory is that sevivus became an adjective in this form, in which the se particle did not have any meaning of its own. Following this view, we could think that at least one part of the occurrences of the se vivo form was not an ablative absolute, but a dative. ${ }^{48}$ However, it is a rather curious suggestion that the sevivus adjective (the dative of that would be sevivo) and the se vivo ablative absolute would have lived side by side for so long in the same linguistic milieu and neither of them has superseded the other. Finding examples of the dative feminine singular of the supposed sevivus adjective would be sufficient to confirm the theory of Konjetzny, since in this case (in contrast with the masculine singular and the plural) the ending of the dative would be different from that of the ablative. While se vivo can be the dative of a theoretical sevivus or an ablative absolute from se and vivus, sevivae could only be seen as a dative. However, we have not found any occurrences of the aforementioned form, in the same time we have almost two hundred examples of the se viva ablative absolute from Rome. Thus, there does not seem to be enough evidence to prove Konjetzny's theory of the sevivus adjective.

After the complicated situation of the masculine singular, we are going to take a look on the feminine. There are 185 examples of se viva ${ }^{49}$ and 2 of se vivam..$^{50}$ Besides, there are 2 inscriptions in which the masculine form was used instead of the feminine. Since the feminine nominative and ablative forms have the same endings $(-a)$, it is impossible to distinguish the correct ablative absolute (that is the pair of the masculine se vivo) from the contaminated form (like se vivus). Maybe this high similarity was the reason of the almost absolute absence of the examples in accusative (se vivam), while in the masculine gender, the se vivum form was relatively frequent. But we need to take into account the fact that the -am ending of the feminine accusative was also pronounced the same way as the ablative and the nominative, because of the weakness of the word-final nasal. Therefore we can presume that among the 185 se viva, there are some hidden accusatives without the final $-m$.

45 E.g. AE 2002, 1230: D(is) M(anibus) | Aurelia | Marcia | ipsa viva | sibi et ca | ro coniu | gi Ravio de | functo hanc | memoriam posuit (Aurelia has made this tomb during her lifetime for herself and for her darling husband, Ravius).

46 Galdi (2004: p. 467): „si nota un chiaro indebolimento del valore del riflessivo.”

47 Konjetzny (1907: p. 323).

48 Pater filio sevivo fecit would mean 'Pater filio vivo fecit' (Father has made it for his living son).

49 E.g. AE 1940, 162: Secundina se vi ' v=B ' a emi<t> (Secundina has bought it during her lifetime).

50 E.g. ILCV, 3866: (...) lo|cum ' v=B 'ero quem sibi ' $\mathrm{v}=\mathrm{B}$ 'enerabi|lis abbatissa Gratiosa prepa|ra ' v=B ' erat se vi ' $\mathbf{v}=\mathbf{B}$ ' $\mathbf{a}\{\mathbf{m}\}$ (...) (the place, which the venerable Gratiosa abbess has ordered during her lifetime, ...). 


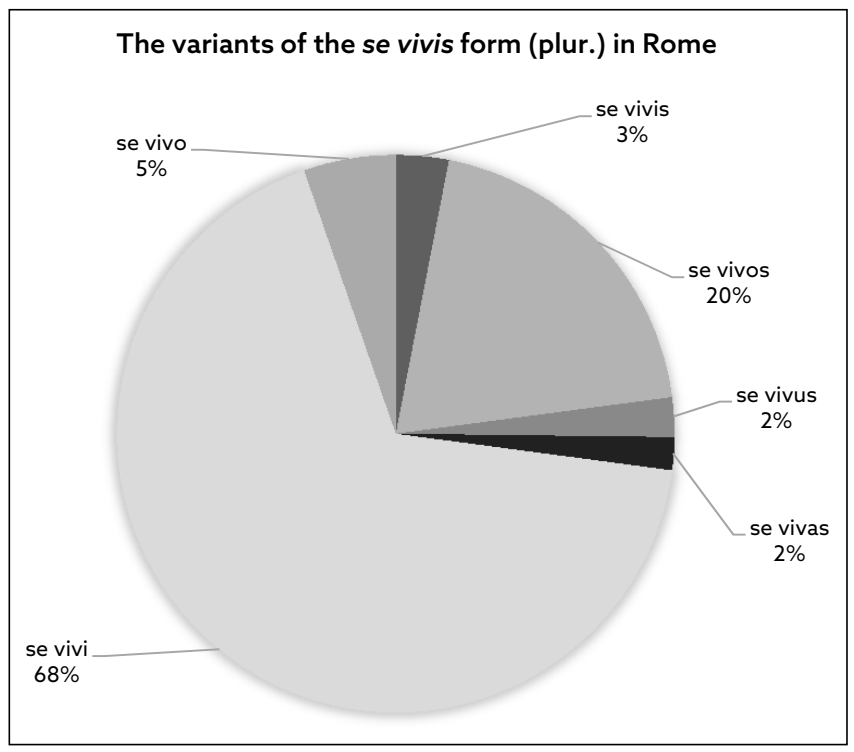

\section{6. chart}

Finally, we focus on the plural, which raises more interesting questions. We have only 8 se vivis (ablative) ${ }^{51}$ beside 52 se vivos (accusative masculine), ${ }^{52} 6$ se vivus (which is an accusative plural ${ }^{53}$ derived from se vivos), 5 se vivas (accusative feminine), ${ }^{54} 177^{55}$ se vivi (nominative masculine) ${ }^{56}$ and 14 se vivo ${ }^{57}$ (that is singular instead of plural or an accusative without a word-final $-s$ ). The most remarkable feature is the minimal proportion of the correct ablative absolute. Evidently, the proportions of correct and incorrect forms generally indicate something about the cultural situation of a region and not about the linguistic changes, but when the percentage of the regular form is only around $3 \%$, it should be explained in its own right.

51 E.g. ICUR IX, 24231. Zabon et Victoria se vi $\mathbf{~ v = B}$ 'is | sibi et Felicissimo filio | fecerunt in pace (Zabon and Victoria have made it during their lifetime for themselves and for their son, Felicissimus. In peace).

52 E.g. ICUR 5, 13304: Bonosus pater orfanu[s et Vic $]$ tor $<\mathrm{i}>\mathrm{a}$ uni ${ }^{\circ} \mathrm{c}=\mathrm{K}{ }^{\prime}$ a $\mid$ filia fecimus no'bi=O ${ }^{\prime} \mathbf{s}$ vi ' vi=BO 's $\mathrm{Iu}[\mathrm{lio}]$ | <H>ermogeneti dulcissim[o uni]co filio (We - Bonosus, the orphaned father, and Victoria, his only doughter - have made it during our lifetime for Hermogenes, the only son).

53 E.g. ICUR I, 1642. Herc $<\mathrm{u}>$ lanius et Claudia | se viv' $\mathbf{i}=\mathbf{V}$ 's emerunt $\mathrm{a}<\mathrm{b}>\mid$ Aurentino ' $\mathrm{f}=\mathrm{E}$ ' ossore (Herculanius and Claudia have bought it during their lifetime from the gravedigger, Aurentinus).

54 E.g. ICUR VI, 15516. Zanesis et Dignitas (...) se viv' $\mathbf{i}=\mathbf{A}$ 's sibi fec $\{\mathrm{i}\} \mathrm{e} \mid$ runt domum aeternalem (Zanesis and Dignitas (...) have made it during their lifetime for themselves as their eternal house).

55 Excluded the 20 occurrences of se vivi[.

56 E.g. CIL VI, 13120. Quieti aeternae | Aurelius Hermes et Claudia Secunda | hoc mon ' u=O `mentum $\mathrm{v}^{\prime} \mathrm{i}=\mathrm{Y}^{\prime}$ rgine $<\mathrm{u}>\mathrm{m}$ se | vivi<s> comparaverunt sibi et | filiis suis et libertis libertabusq(ue) | posterisque eorum (For their eternal rest, Aurelius Hermes and Claudia Secunda have bought this intact tomb during their lifetime for themselves, for their sons, freedmen, freedwomen and the descendents of them).

57 E.g. ICUR 1, 1565. Concordia et Tigrinus filius | se viv' is $=\mathbf{O}{ }^{`}$ fecerunt (...) (Concordia and her son, Tigrinus have made it during their lifetime...). 


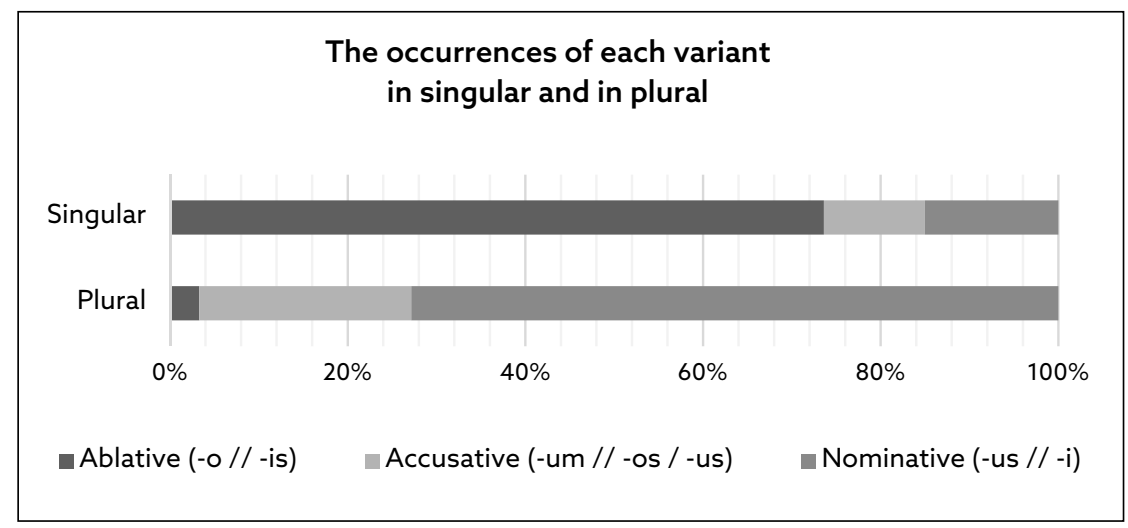

\section{7. chart}

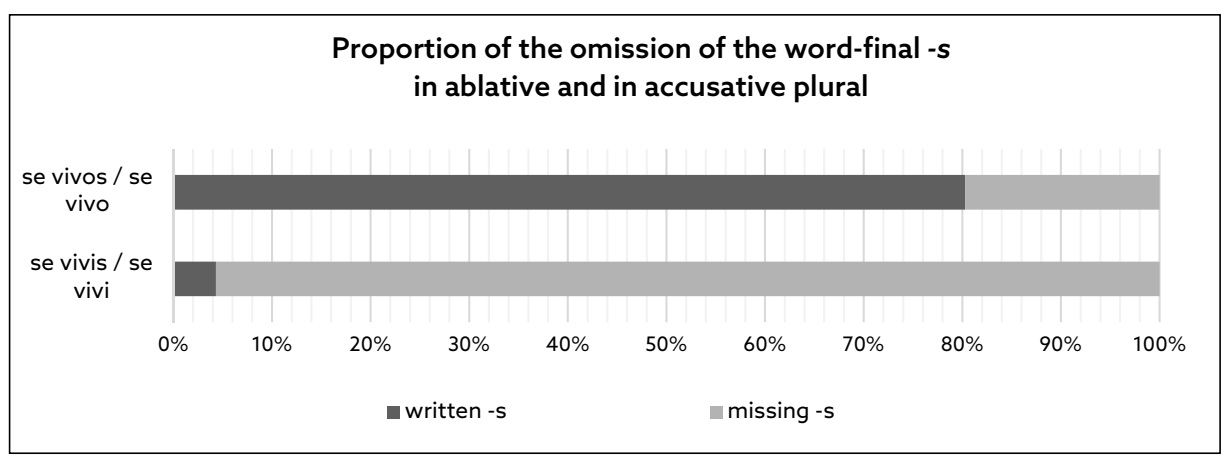

\section{8. chart}

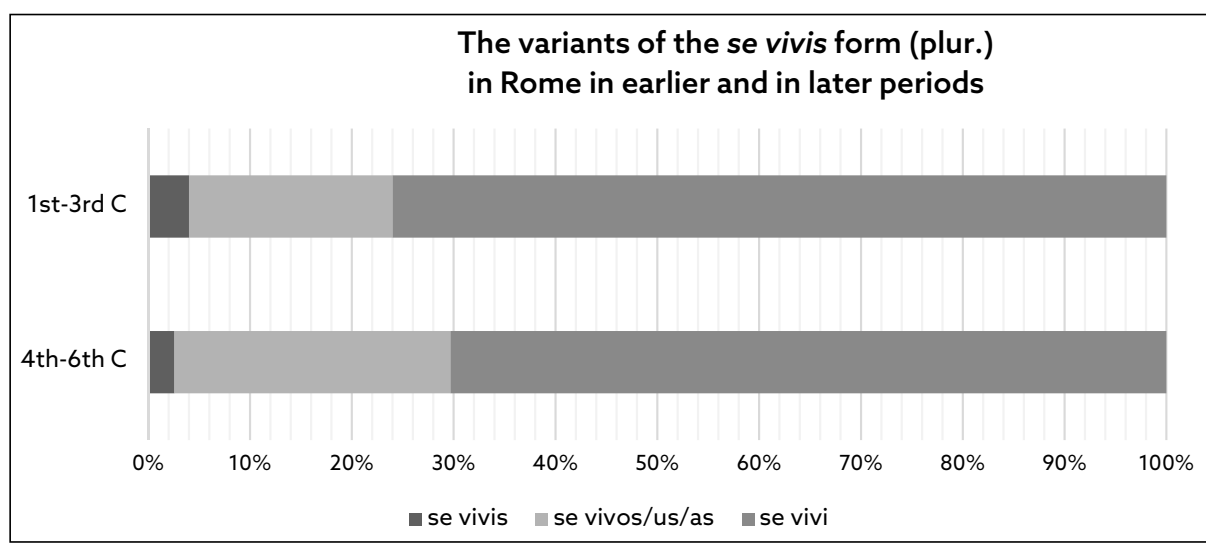

\section{9. chart}


Furthermore, if we compare the distribution of the cases of the singular to that of the plural (chart 7) ${ }^{58}$ the contrast is apparent. In plural, the ablative (se vivis) is radically reduced, while the form with nominative (se vivi) is much more frequent than the singular se vivus. There is no such speaker who is more educated when $\mathrm{s} /$ he uses the singular. We have also relatively more accusative in plural, but that difference is not significant.

To explain the high number of se vivi instead of se vivis is quite problematic. We cannot answer the question based on morphology, because if it were the same phenomenon as in singular (that is like se vivus form instead of se vivo), similar proportions could be expected. Besides, we know many inscriptions using the accusative plural of the adjective (se vivos), which could have appeared only as a result of an ablative-accusative confusion. So, at least a significant portion of the examples of se vivi must be an ablative without a word-final $-s^{59}$

Thus, we could affirm, that the se vivi form is generally an ablative absolute, where the adjective has lost its final consonant. Nevertheless, at the same time we see the other forms ending to an -s. For example, if we supposed that the 14 data of se vivo with plural predicate were not ablative absolutes in singular but all were derived from se vivos, the examples of the form with $-s$ would obviously be in majority (we have 58 of them), as it can be seen on the eighth chart. Why would the word-final $-s$ be more fixed in the case of se vivos respect to that of se vivis?

According to the literature on the history of the Latin language, the vanishing of the final $-s$ in Middle and Southern Italy is a relatively late change. ${ }^{60}$ If we could prove that the majority of the inscriptions with se vivi are from the later centuries, we would be more convinced about the phonological origin. But if we look at the distribution of the cases in earlier and in later periods (chart 9), we get the opposite result. The se vivi form was as much often used during the first three centuries as later. So, the explaining the high number of the se vivi forms by the vanishing of the word-final $-s$, or by the confusion of the nominative and ablative is hardly sufficient. Nevertheless, at this point, we could not come up with any alternative explanation.

Beyond the foregoing problem of the se vivi forms, the last chart attracts our attention to one more unexpected phenomenon. If we compare the last chart to the similar chart of singular forms, ${ }^{61}$ we can notice that while in the singular using the forms with accusative-ablative confusion was a characteristic only of inscriptions from the $4^{\text {th }}-6^{\text {th }}$ centuries, in the plural it was almost as frequent in the earlier periods as in the Christian times. We cannot account for the fact that it has appeared earlier in the plural than in the singular. Especially, since the phonetic similarities that made the ablative-accusative

58 The examples in feminine are excluded, as also are the se vivo form next to plural predicate. In our opinion, the se vivus form with plural predicate is derived from the se vivos (thanks to the mentioned vocalic mutation), so these examples are counted in the group of the plural accusative. The possibility that it is a fossilized nominative singular (which is already grammatically incorrect!) referring to a plural subject, is very low. We prefer to suppose the obviously well spread vocalic change.

59 See fn. 40.

60 Herman (2000: pp. 40-41).

61 Cf. 5. chart. 
confusion more simple in the singular (accusative ending: - um with a weak nasal, ablative ending: mid-close -o) were not present in plural.

At last, we take a look at a phenomenon generally mentioned by the literature of the topic: the fossilization of the expression in the se vivo form (in the masculine singular). Väänänen notes that the formula occasionally stands in this form with a feminine or plural subject, Hofmann \& Szantyr's work on Latin grammar attributes the irregular forms to the fossilization of the formula. ${ }^{62}$ This opinion cannot be interpreted easily, since the fossilization ${ }^{63}$ should prevent the formula from following the mutations of the language. We can find the se vivo form instead of the se viva 8 times with singular feminine subject, ${ }^{64}$ and 19 times with plural subject in the place of se vivis. ${ }^{65}$ The occurrences of the se vivo in plural sentences do not certainly mean the fossilization of the formula, since the se vivo form with plural subject can also be a form derived from se vivos. This explanation seems more probable if we take into account that 14 of the 19 data are from Rome (where we know many examples of se vivos), while the 8 examples in which we can see se vivo with feminine subject are from distant parts of the empire. If we take the major part of the se vivo forms with plural subject as derived from se vivos, then only about 10 examples of forms without grammatical agreement remain from the whole empire. This amount of the occurrences is obviously too low to prove the fossilization of the expression.

To sum up the second part of the paper: there was an ablative absolute construction in which the adjective of the expression was not always in ablative, we can find it in nominative or in accusative. The forms with nominative are more problematic, because the reflexive pronoun does not have a nominative case in classical Latin. There are more divergences between the singular and the plural: we cannot explain the high proportion of the forms using a nominative adjective (se vivi) compared to those using ablative in the plural, a phenomenon we do not find in the singular. In addition, the frequent use of the accusative in the earlier centuries only in plural is another yet unanswered question. To be able to proceed the study of the phenomenon, we have to make more investigations on the general tendencies of the linguistic processes, concentrating on the dependence of the phonetic and morpho-syntactic changes.

62 Väänänen (1981: p. 167), Hofmann \& Szantyr (1972: p. 141).

63 In my interpretation, fossilization means that a formula becomes independent of the grammatical context (in our case of the number or the gender of the subject). We can speak of a "fossilized formula" if it is usually used in the same form, without any change, independently of the word it refers to.

64 AE 1965, 86; CIL II, 3509; CIL III, 14584; ILJug III, 1296; CIL VIII, 4171; CIL VIII, 7512; ICUR I, 867.

65 CIL III, 12381; CIL VI, 8800; CIL VI, 15423; CIL VI, 21511; CIL VI, 35964; CIL VI, 38053; ICUR VII, 18026; ICUR I, 1565; ICUR II, 4756; AE 2003, 217; ICUR I, 902; ICUR IV, 11479; ICUR VII, 19175; ICUR VIII, 20833 a; ICUR VIII, 20833 b; AE 2011, 322; IMS VI, 111; AE 1993, 1352; AE 1964, 271. 


\section{Bibliography}

Adamik, B. (2009). In Search of the Regional Diversification of Latin: Some Methodological Considerations in Employing the Inscriptional Evidence. In F. Biville et al. (Eds.), Latin vulgaire Latin tardif, I: Actes du IXe colloque international sur le Latin vulgaire et tardif (pp. 123-139). Lyon: Maison de l'Orient e la Méditerranée.

Adamik, B. (2016). Computerized Historical Linguistic Database of the Latin Inscriptions of the Imperial Age: Search and Charting Modules. In From Polites to Magos: Studia György Németh Sexagenario Dedicata (Hungarian Polis Studies, XXII; pp. 13-27). Budapest - Debrecen: University of Debrecen, Dept. of Ancient History and Class. Phil.

Adamik, B. (2017). The problem of the omission of word-final -s as evidenced in Latin inscriptions. Graeco-Latina Brunensia, 22(2), 5-21.

CIL VI. = Henzen, G. et al. (1876-1885). Inscriptiones Urbis Romae Latinae (Corpus Inscriptionum Latinarum, VI). Berolinum: Georgius Reimerus.

EDCS = Clauss, M., Kolb A., \& Slaby, W. A. Epigraphik-Datenbank Claus / Slaby [retrieved 18.02.2018. from http://db.edcs.eu/epigr/].

Galdi, G. (2002). Reflexive and possessive pronouns in Greek and Latin inscriptions of the Empire (Moesia Inferior). In G. Calboli, Papers on Grammar (Vol. V; pp. 75-94). Bologna: Clueb.

Galdi, G. (2004). Grammatica delle iscrizioni latine dell'impero (province orientali). Roma: Herder.

Herman J. (2000). Vulgar Latin (transl. R. Wright). University Park, Pa: The Pennsylvania State University Press.

Hofmann, J. B, \& Szantyr, A. (1972²). Lateinische Syntax und Stilistik. München: C. H. Beck'sche Verlagsbuchhandlung.

ICUR = Silvagni, A. et al. (1922-1992). Inscriptiones christianae urbis Romae septimo saeculo antiquiores. Nova series (Vol. I-X). Roma: Officina Libraria Doct. Befani (Vol. I-II); Civitas Vaticana: Pont. Institutum Archeologiae Christianae (Vol. III-X).

Konjetzny, G. (1907). De idiotismis syntacticis in titulis latinis urbanis (CIL vol. VI) conspicuis (Archiv für lateinische Lexikographie und Grammatik, XV). Leipzig: Teubner.

LLDB = Adamik, B. et al. Computerized Historical Linguistic Database of Latin Inscriptions of the Imperial Age [retrieved 18. 01. 2018 from http://lldb.elte.hu/].

Martin, H. (1909). Notes on the Syntax of the Latin Inscriptions Found in Spain. Baltimore: J. H. Furst Company.

Menge, H. $\left(2009^{4}\right)$. Lehrbuch der lateinischen Syntax und Semantik. Darmstadt: Wissenschaftliche Buchgesellschaft.

Väänänen, V. (1981³). Introduction au latin vulgaire (Librarie Klincksieck, série linguistique, 18). Paris: Klincksieck.

Nóra Zelenai / nori.zelenai@gmail.com

Doctoral School of Linguistics, Ancient Studies Doctoral Programme

Eötvös Loránd University, Faculty of Humanities

Múzeum krt. 4/F, 1053 Budapest, Hungary 